\title{
The Place of the Criminal Justice for Children in the Legal System of Republic of Macedonia from Its Independence Until Today
}

\author{
Blerta Arifi PhD \\ Faculty of Law \\ Besa Kadriu PhD \\ South East European University, Tetovo, Republic of Macedonia
}

\begin{abstract}
In this paper the author will analyze the legal treatment of juvenile delinquency in Republic of Macedonia, in historical aspect of the development of its legislation. In this way it will be presented the place of the criminal law for juveniles in the criminal legal system of the country and its development during today. The study will be focused on the innovation of legal protection of delinquent children, especially it will be analyzed the sanctioning of juvenile perpetrators and their special treatment from the majors in Republic of Macedonia. It will be a chronological comparison reflect of the juvenile sanctioning based on some of laws in Macedonia such as: Criminal Code of Former Yugoslavia, Criminal Code of Republic of Macedonia (1996), Law on Juvenile Justice (2007) and Law on Child protection (2013). The purpose of the study is to bring out the types of criminal sanctions for juveniles in Republic of Macedonia from its independence until today which, above all, are aimed on protecting the interests of the juvenile delinquents. Also the author of this paper will attach importance to the so-called "Measures of assistance and protection" provided by the Law on Child protection of Republic of Macedonia, which represent an innovation in the country's criminal law. This study is expected to draw conclusions about how it started to become independent itself the delinquency of minors as a separate branch from criminal law in the broad sense - and how much contemporary are the sanctions to minors from 1996 until today.
\end{abstract}

Keywords: Sanctioning of minors juvenile delinquency, criminal legal system, measures of assistance and protection.

\section{Introduction}

The basic idea of the definition for this research is the challenge of solving the dilemma for the legal nature of criminal justice for children, an independent positive branch of law in the Legal Criminal Code of the Republic of Macedonia, or as it is presented as an integral part of the criminal law in general?

This question arises during a chronological analysis of the development of criminal law for children within the criminal justice system of the Republic of Macedonia. When analyzed, criminal justice in our country from its independence until today, will be faced with a large number of laws that are repealed by new ones and have been amended several times with the others, and this puts the researcher in front of a challenge to analyze all those legal changes that are in its interest. In this case it will be examined how criminal justice for children is regulated by the criminal legislation of Republic of Macedonia.

\section{Research Methodology:}

\subsection{Methods}

In this research will be a chronological overview of the development of criminal justice for children in Republic of Macedonia in the framework of legal regulation in this field. It will be presented chronologically its legal treatment from its independence until today, which will come out also on the development of this branch of law. 
There will be compared in parallel these laws: The Criminal Code of the Republic of Macedonia (1996); The law on juvenile justice of the Republic of Macedonia (2007) and the Law on Justice for Children of Republic of Macedonia (2013), in the following aspects. The categorising of juveniles, the principles on which the criminal law for children / minors is based, types of criminal sanctions and other non-criminal measures.

To the paper are attached some statistical data released by the state statistical Office of the Republic of Macedonia, regarding the number of minors sentenced in Republic of Macedonia from the years 2006-2015, as well as coverage of criminal sanctions imposed by the courts of country to the minors convicted. And we will be able to draw some conclusions regarding the development of criminal justice for children in Macedonia.

\subsection{Findings and discussion:}

Criminal justice system of the Republic of Macedonia has been operating five years after its independence (1991) with the Criminal Code of Macedonia ${ }^{1}$ of the former Yugoslav Federation until 1996 when it became effective the new Criminal $\mathrm{Code}^{2}$. Within this Code is regulated the activity of competent state bodies with minors who are appear to the society as delinquent of different criminal acts. Namely until 2007, the Criminal Code has been effective with the 70-96 articles in a special chapter dedicated to the juvenile delinquency entitled " Educational measures and punishment of minors", where are provided all repressive measures which can be sentenced to guilty minors under conditions provided by that law.

In 2007, there was approved a special law regulating this field, the Law on Juvenile Justice of Republic of Macedonia ${ }^{3}$, which comes into effect from 1 September 2008 and beside abolishes the provisions of Chapter 6 of the aforementioned Criminal code (1996). So that at this moment criminal justice starts to get separated from Criminal code and to gain a more autonomous nature of building in its aspect with detailed. And the last law which regulates the criminal justice for children, is the Law on Justice for Children of the Republic of Macedonia4, 2013. This law is in force and it regulates in detail the entire treatment of children who are in conflict with the law or represent victims of crime.

\section{2.a. Underlying the principles of criminal justice for children in the Republic of Macedonia - comparative aspect of the laws which regulate this area}

-The provisions of the Criminal Code of the Republic of Macedonia that regulated the area of criminal justice for children, had determined the basic principles upon which was built and operated the preventive-repressive system of juvenile delinquency. The rule of excluding the criminal sanctions from children under 14 years old stayed on top of the list of the main principles of the Criminal Code of Republic of Macedonia. ${ }^{5}$

Very important principle is the proclamation of the idea of preventive character of the criminal sanctions which can be was imposed to juveniles convicted and beside the purpose of educational measures, sentencing and alternative measures is to provide assistance and protection to minors, and supervised them; for professional development and their responsibility, and to achieve the main goal, which is education, rehabilitation and their right development. ${ }^{6}$ This principle continues to be very effective along the criminal law for children, up to the present day.

Also in this article it is proclaimed the principle of special and general prevention in the context of the purpose of sentencing the juvenile prison, which although is as a final alternative, for those juveniles who have reached age 16 year. Other principles are not defined in the Code explicitly and specifically to minors, because of the general principles outlined in it that apply also to adult persons and which are not contrary to those principles mentioned above.

\footnotetext{
${ }^{1}$ Criminal Code of Republic of Macedonia "Official list of SFRJ" no 44/74, 34/84, 74/84, 57/89, 3/90,38,90 and Official Journal of R.M. no 25/92 and 32/93, and "Official Journal of SRM" no. 25/77, 23/84, 50/87, 36/89,7/90, 23/91, 24,92,49/93.

2 Criminal Code of Republic of Macedonia, Official Journal/year: 37/1996

${ }^{3}$ Law on Juvenile Justice of Republic of Macedonia, "Official Journal of R.M."no. 87/2008, 103/2008, 161/2008, 145/2010.

4 Law on Justice for Children of Republic of Macedonia, "Official Journal of R.M." no. 148/2013.

${ }^{5}$ Criminal Code of Republic of Macedonia, 1996, Article 71

${ }^{6}$ Criminal Code of Republic of Macedonia, 1996, Article 73 
-The Law on Juvenile Justice of the Republic of Macedonia (2007), provided some other principles explicitly, but also including the principles upon which was based the juvenile delinquency regulated with the Criminal Code until then. Those principles are as following here below:

The principle of legality, one of the main postulates of criminal law in general (Article 3 of the Juvenile Justice Law, 2007); The equal treatment of minors as adults during the course of informal and criminal procedure (Article 4) The purpose of sanctioning the minor which is in the interest of defense, education, rehabilitation and fair development of minors(Article 5) - A principle which is repeated again, with what you foresaw in the Criminal code.

Another important principle is giving priority to preventive protective and education measures compared with the sanctions provided for by this law (Article 7). It also proclaimed the principle of individualization of the criminal sanction I measure for the juvenile who commits criminal offense. ${ }^{1}$ Even this law provides that the principle of avoidance the minors on front of criminal proceedings, except in cases provided by this law (Article 9), we will inevitably cases to adjudicate only competent court to judge delinquency of minors. ${ }^{2}$

-With the Law on Justice for Children of Republic of Macedonia there are defined the fundamental principles based on which is based the functioning of the criminal justice, and they are: The right to use the language, the right to be informed at every stage of the criminal proceedings, the prohibition of discrimination on any base, principle of legality, the prohibition of cruel inhuman and degrading treatment, deprivation of liberty of juveniles only as a last resort in procedure, protecting the interest of the child to education, the right to appeal, the priority of preventive measures, education and protection, the principle of individualization of punishment, etc. ${ }^{3}$

\section{2.b. Categorizing of minors by age}

It should be noted that although criminal justice for children has faced modifications over time, it did not change the minimum age limit for minor incrimination of persons who commit offenses. There we can definitely outline a very important principle that provides the law on justice of children, "the child who at the time of the commission of the act that the law is foreseen as a criminal offense or offenses not has reached 14 years, can not be applied sanctions defined by this law." ${ }^{4}$ All criminal laws of Republic of Macedonia have determined the criminal liability limit by the age on 14 years and the completion of a minor (childhood) the aged 18 years. But what is bringing innovation to the last laws on Justice for Children, are the socalled Help and protection-measures which are not imposed in offense of non-criminal procedure, of which may be imposed on persons who were not having attained the age of 14 years old at the time of the commission of any offense.

\section{2.c. The 2 nd difference on laws on childen- The categorization of minors by age: ${ }^{5}$}

Under the old provisions of the Criminal Code (1996) and the law on juvenile justice (2007) children were classified into several groups, partitioning it, which is more detailed, in comparison with divisions that were merely the minors with the previous laws, according to them there are only categories of juveniles: Junior minors (14-16 years) and adult minors (1618 years). ${ }^{6}$ By the current law in force children are divided as it follows:

- child is any person under 18 years,

- children at risk every child has reached seven years and has not attained 18 years of age with physical or obstacles mental development, a victim of violence, neglected aspect educational and social, who is in a situation in which it is hampered or prevented realization educational function of the parent / $\mathrm{s}$ or guardian / $\mathrm{s}$, which is not included in the education system and education, involved in begging, weaving or prostitution, which uses drugs and other psychotropic substances and precursors or alcohol, and who because of these conditions is or may be contrary to law as a victim or witness the action as provided by law as an offense or act that is prescribed by law as a criminal offense,

\footnotetext{
${ }^{1}$ Law on Juvenile Justice of Republic of Macedonia, "Official Journal of R.M."no. 87/2008, 103/2008, 161/2008, 145/2010, Article 8

2 Law on Juvenile Justice of Republic of Macedonia, "Official Journal of R.M."no. 87/2008, 103/2008, 161/2008, 145/2010,Article 11

${ }^{3}$ Law on Justice for Children of Republic of Macedonia, "Official Journal of R.M." no. 148/2013, Articles 3-16

4 Law on Justice for Children of Republic of Macedonia, "Official Journal of R.M." no. 148/2013, Article 20

${ }^{5}$ Law on Justice for Children of Republic of Macedonia, "Official Journal of R.M." no. 148/2013, Article 19

${ }^{6}$ Criminal Code of R.M. Official Journal/year: 37/1996, Article 72
} 
- children at risk by age 14 years is any child who at the time of the offense prescribed by law as an offense for which he was prescribed fine or imprisonment for more than three years or criminal prescribed by law as an offense, is aged seven years and has not reached 14 years,

- children at risk from 14 to 18 years is any child who at the time of transaction, foreseen by the law as an offense for which he was prescribed fine or imprisonment up to three years or work provided by law as an offense, has not reached 14 years of age of 18 years,

- children that conflicts to the law from 14 to 16 years is any child who at the time of transaction prescribed by law as a criminal offense which can be punished with imprisonment over three years has reached 14 years and did not 16 years of age,

- children that conflicts to the law over 16 years is any child who at the time of transaction prescribed by law as a criminal offense which can be punished with imprisonment over three years, has turned 16 years has not filled 18 years,

- child victim is any child aged up to 18 years who has suffered harm, including physical injury or mental, incurrence emotional, material loss or other breach or threaten the rights and interests as a result of action taken by law provided as a criminal offense,

- the youngest adult person is a person who during the trial for action prescribed by law as a criminal offense, the age of 18 years to the age of 21 years.

Despite this division, if we analyze the content of these provisions still remain the same limit criminal responsibility of minors, ie children, from age 14 to age 18, who are now in positive law Justice for Children denominated " children in conflict with the law "by the age of $14-18$ years."1

\section{2.d. Types of criminal sanctions for children in Macedonia based on Law on Justice for Children of Republic of Macedonia(2013)}

There two main types of sanctions: Educational measures and penalties. Following will appear all divisions of these two types of criminal sanctions. Types of educational measures: ${ }^{2}$

(1) Children older than 14 years for acts provided by law as a criminal offense that may be imposed on the following educational measures:

- Measures rebuke or referral center for children

- Reinforced supervision measures by the parent / s or tutor / s, or centers and foster family

- Entity measures by sending in educational institutions or in educational and correctional home.

(2) Measure warning or referral center for children is sentenced to the child when there is a need for longer measures of education, especially if committed an act which the law has prescribed as a criminal offense out of thoughtlessness or folly.

(3) Measures of intensive supervision of children when there is a need imposed by longer measures of education, rehabilitation or treatment with appropriate supervision, do not need their complete separation from current environment.

(4) imposed measures of child entity when there is a need of long measures of education, rehabilitation or treatment and complete separation from current environment. The duration of these measures can not be longer than five years, but mostly by filling 23 years.

To the child at risk until the age of 14 years and children at risk on the age of 14 years shall apply the measures provided by law for help and protection, which are of interest to the child and his development and education." (Article 21)

\footnotetext{
1 Law on Justice for Children of Republic of Macedonia, "Official Journal of R.M." no. 148/2013, Article 19

2 lbid. Article 37 
Assistance and protection measures are measures prescribed by law in the area of education, health, social, family and other forms of protection. (Article 22)

Although the law does not define which are these measures precisely, in practice, some of these measures encountered are: Mediation between the minor and the injured party mediation between the minor and his family, compensation of damages to the injured party attendance regular school, employment or training for a profession, Performance of unpaid community education in general traffic rules, etc. psychological counseling.

Also below will appear explicitly types of sentences for children over 16 years:

(1) Can be punished a child over the age of criminal responsibility to 16 years, unless due to the severe consequences of the offense committed and the high degree of criminal responsibility would not be reasonable to impose educational measure.

(2) Under the conditions established by this law, children over the age of 16 years may be imposed the following penalties:

- Jail for children

- Fine,

- prohibition of driving certain type or category of motor vehicle and

- deportation of foreigners from the country.

2.2.e. Representation of the situation of criminal justice for children in the Republic of Macedonia, as seen from the data published by the State Statistical Office of Macedonia

Table 1: Convicted children in republic of Macedonia during years 2006-20151

\begin{tabular}{|c|c|c|c|c|c|c|c|c|c|c|}
\hline$T$ & 2006 & 2007 & 2008 & 2009 & 2010 & 2011 & 2012 & 2013 & 2014 & 2015 \\
\hline $\begin{array}{l}\text { T } \\
\text { A } \\
\text { L }\end{array}$ & 844 & 676 & 715 & 748 & 547 & 722 & 556 & 473 & 461 & 348 \\
\hline
\end{tabular}

The table 1 shows the number of children sentenced in the Republic of Macedonia during the years 2006 to 2015. From these data it can be seen that the criminality of minors in the Republic of Macedonia goes diminishing in recent years, especially if we compare years prior to the latest research with them. From these results it can be concluded that with law changes in implementation of preventive measures and those of assistance and protection for children have shown success and are presented as alternative of convictions.

In table 2 can be seen types of penalties they have imposed on the courts of the Republic of Macedonia during 2015 to total 348 convicted children.

Also shown is their gender, it can be observed that only a very small number of them, then sentenced to 22 are female. Of this number 73 are children aged 14-16 years old on whom penalties are imposed such as: rebuke, and say are ltensified Most of Supervision by parents and by a social agency!

Table 2: Convicted children by types of criminal offences, attempt, sex and penalties during 20152

\begin{tabular}{l|l|l|}
\hline$T$ & Total & Children aged 14 to 16 years \\
\hline
\end{tabular}

1Perpetrators of criminal offenses in 2015, Skopje: State Statistical Office of the Republic of Macedonia, 2016 http://www.stat.gov.mk/Publikacii/2.4.16.08.pdf,T-30.

2 bid.T-33 


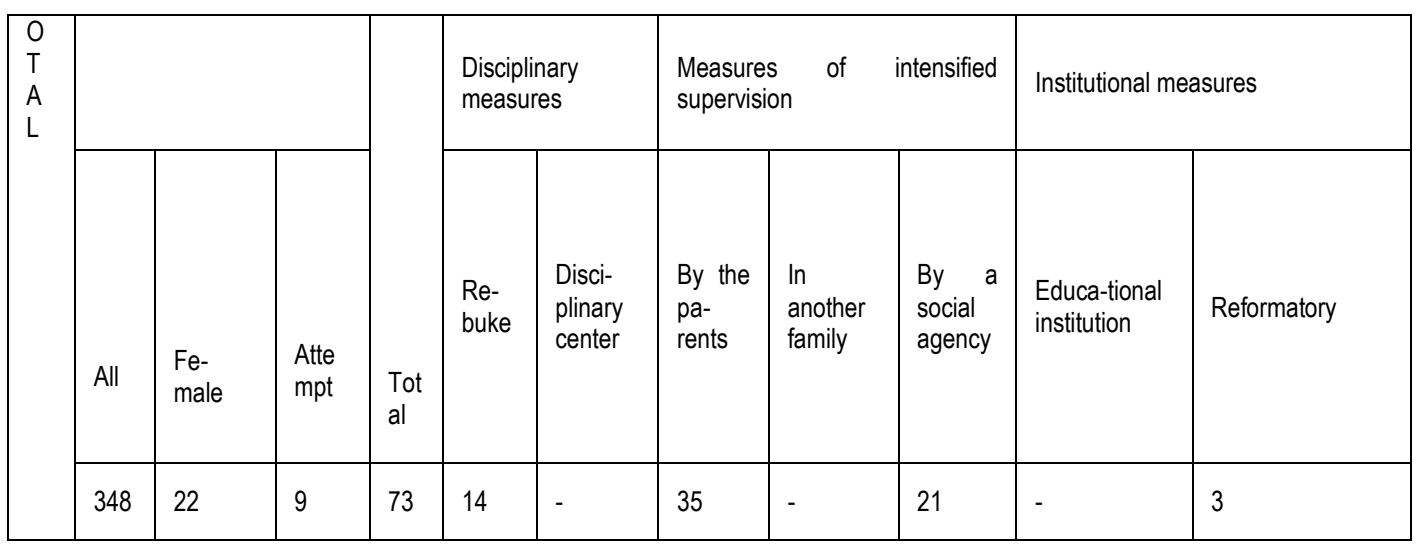

In Table 3 it is reflected the number of penal sanctions imposed in 2015 against children aged 16-18 who have committed crimes in the Republic of Macedonia. In this case we see a number of satisfactory priority that educational measures compared with the imprisonment for children, which is a very low number compared to the first. This proves that the courts respect the principle of detention as a last resort the procedure for minors!

T-3 Convicted children aged 16 to 18 years by penalties during $2015^{1}$

\begin{tabular}{|l|l|l|l|}
\hline \multirow{2}{*}{ TOTAL } & \multirow{2}{*}{275} & Child imprisonment & Educational measures \\
\cline { 3 - 4 } & & 8 & 267 \\
\hline
\end{tabular}

\section{Conclusions}

The criminal justice for children in Republic of Macedonia although it is independent with special law on child justice, in which are regulated all its institutions, principles, criminal sanctions and other non-criminal measures for children and the criminal procedure for children, it still remains dependent on criminal law in the broad sense, in terms of treatment of general principles and institutions that regulate this branch of law within the legal system of the country.

\section{References}

[1] Criminal Code of Republic of Macedonia, Official Journal/year: 37/1996

[2] Law on Justice for Children of Republic of Macedonia, "Official Journal of R.M." no. 148/2013,

[3] Law on Juvenile Justice of Republic of Macedonia, "Official Journal of R.M." no. 87/2008, 103/2008, 161/2008, 145/2010.

[4] Perpetrators of criminal offenses in 2015, Skopje: State Statistical Office of the Republic of Macedonia, 2016. http://www.stat.gov.mk/Publikacii/2.4.16.08.pdf

[5] www.pravo.org.mk

\footnotetext{
${ }_{1}$ Perpetrators of criminal offenses in 2015, Skopje: State Statistical Office of the Republic of Macedonia, 2016. http://www.stat.gov.mk/Publikacii/2.4.16.08.pdf, T-34 